\title{
Lipofuscin-Like Substance Involved in Pericarp Browning of Postharvest Litchi Fruit During Storage
}

\author{
Shaoyü Yang ${ }^{1,2}$, Jian Sun ${ }^{1}$, Linyan Feng ${ }^{1,2}$, En Yang ${ }^{1,2}$, Yulong Chen ${ }^{1,2}$, Xinhong Dong ${ }^{1,2}$, \\ Xinguo $\mathrm{Su}^{3}$ and Yueming Jiang ${ }^{*}, 1$ \\ ${ }^{1}$ South China Botanical Garden, Chinese Academy of Sciences, Guangzhou Leyiju 510650, The People's Republic of \\ China \\ ${ }^{2}$ Graduate School, Chinese Academy of Sciences, Beijing 100039, The People's Republic of China \\ ${ }^{3}$ Food Science Institute, Guangdong Food and Drug Vocational-technical School, Guangzhou 510650, The People's \\ Republic of China
}

\begin{abstract}
Litchi (Litchi chinensis Sonn.) is a subtropical fruit of high commercial value in international trade. However, litchi fruit after harvest can rapidly lose their bright red skin color and turn brown with increasing storage time at ambient temperature. Postharvest browning of litchi fruit is mainly attributed to the degradation of anthocyanins and the oxidation of phenolics. In this study, the contents of lipofuscin-like substance in relation to the levels of anthocyanins and (-)epicatechin, and browning index of litchi fruit during storage were investigated. In a storage period from 72 to $144 \mathrm{~h}$, the relative content of lipofuscin-like substance increased by $51.1 \%$ while the contents of (-)-epicatechin and anthocyanins decreased by 41.2 and $98.1 \%$, respectively, and the obvious accumulation of lipofuscin-like substance of pericarp tissue of litchi fruit was related to the reduced contents of anthocyanins and (-)-epicatechin. Furthermore, the increase in the content of lipofuscin-like substance was significantly related to the increased browning index. It is suggested that lipofuscinlike substance could be one of the final products from the browning reaction of litchi fruit during storage.
\end{abstract}

Keywords: litchi, browning, lipofuscin-like substance, anthocyanin, (-)-epicatechin.

\section{INTRODUCTION}

Lipofuscin-like substance is the final product of the autooxidation of molecular components such as lipid hydroperoxides, malondialdehyde and protein of cells $[1,2]$, and are shown to accumulate or increase with increasing age in various plant tissues and to be positively correlated with lipid peroxidation processes [3]. Biological membranes are labile to lipid peroxidation because of their high content of phospholipids and polyunsaturated fatty acids. Positive correlations between tissue senescence and lipid oxidation have been reported in yellowing banana, pear, avocado, litchi and potato and leaf [4-7].

Litchi (Litchi chinensis Sonn.) is a subtropical fruit with high commercial value due to attractive red color and delicious taste [8]. The fruit is highly perishable after harvest due to rapid skin browning which is mainly attributed to the degradation of anthocyanins and oxidation of (-)-epicatechin [9-11]. Enhanced oxidation and peroxidation of harvested litchi fruit during storage could result in the accumulation of lipofuscin-like substance. Lin, Li, Zhang, Lin, Li, Liu \& Chen reported the changes in the contents of pigments and phenolics of litchi fruit during storage and then found that a brown polymeric compound appeared when fruit browned

*Address correspondence to this author at the South China Botanical Garden, Chinese Academy of Sciences, Guangzhou Leyiju 510650, The People's Republic of China; Tel: +86 20 37252525; Fax: +86 20 37252960; E-mail: ymjiang@scib.ac.cn
[12]. Furthermore, Jiang, Duan, Joyce, Zhang \& Li (2004) supposed a mechanism to account for enzymatic browning of litchi fruit pericarp, which is involved in the formation of the brown polymeric pigments [9]. As a yellow brown polymeric pigment, it is suggested that lipofuscin-like substance may be one of the final products from the enzyme-catalyzed browning reaction of harvested litchi fruit but it requires further investigation.

The objective of this study was to investigate the relationship between lipofuscin-like substance and pericarp browning of litchi fruit during storage, and then examine the possible involvement of anthocyanins and (-)-epicatechin into the accumulation of lipofuscin-like substance. This study can help better understand the pericarp browning of harvested litchi fruit during storage.

\section{MATERIAL AND METHODS}

\subsection{Fruit Treatment and Storage Condition}

Litchi (Litchi chinensis Sonn. cv. 'Huaizhi') fruit at the commercially mature stage were obtained from a commercial orchard in Guangzhou. Fruit were selected for uniformity of shape, color and size, while any blemished or diseased fruit were discarded. The selected fruit were dipped for $3 \mathrm{~min}$ in $0.1 \%$ Sportak (a fungicide) solution, air-dried for $2 \mathrm{~h}$, packed in $0.03 \mathrm{~mm}$ thick polyethylene bags (20 fruit per bag with 15 bags), and then stored at $25^{\circ} \mathrm{C}$. Fruit (20 fruit per bag with 3 bags) were taken initially and sampled at a 36-h interval. Fruit pericarp tissues were collected and then frozen for the following analyses. 


\subsection{Fruit Quality Evaluation}

Fruit browning was assessed according to the method of Zheng and Tian [13] by measuring the extent of the total browned area of the inner pericarp of 60 individual fruit, using the following visual appearance scale: $0=$ no browning (excellent quality); $1=<1 / 8$ browning; $2=1 / 8-1 / 4$ browning; $3=1 / 4-1 / 2$ browning and $4=>1 / 2$ browning (poor quality). The browning index (\%) was calculated as the following formula $\sum$ (browning rating $\times$ percentage of fruit within each class) $\times 100 / 4$.

\subsection{Determinations of (-)-Epicatechin and Anthocyanins}

Frozen pericarp tissues $(1 \mathrm{~g})$ were extracted overnight in $4 \mathrm{~mL} 1.5 \mathrm{M} \mathrm{HCl}$ in methanol at $25{ }^{\circ} \mathrm{C}$ by the method of Zhang, Pang, Duan, Ji \& Jiang [10]. The extract was filtered through $\varnothing 0.45 \mu \mathrm{m}$ filters (PVD membrane, Shanghai ANPEL Scientific Instruments Co. Ltd, Shanghai, China). A 20$\mu \mathrm{L}$ aliquot was injected directly into the HPLC system (Shimadzu, Kyoto, Japan). HPLC analysis was performed on a LC-20 AT system (Shimadzu, Kyoto, Japan) using a Shimpack UP-ODS C18 column $(4.6 \times 250 \mathrm{~mm}$, Shimadzu, Kyoto, Japan) at $30{ }^{\circ} \mathrm{C}$. A linear gradient was used from 5 to $100 \%$ acetonitrile in $2 \%$ acetic acid for $30 \mathrm{~min}$ and then 100 to $5 \%$ acetonitrile in $2 \%$ acetic acid for $10 \mathrm{~min}$, with a flow rate of $1 \mathrm{~mL} / \mathrm{min}$. (-)-Epicatechin and anthocyanins were monitored at 280 and $520 \mathrm{~nm}$, respectively. (-)-Epicatechin standard was obtained from Sigma Corporation. Anthocynin content was calculated as cyanidin-3-glucoside by the method of Wrolstad, Culbertson, Cornwell \& Mattick [14]. The contents of (-)-epicatechin and anthocyanins were expressed on fresh weight (FW) basis.

\subsection{Extraction and Determination of Lipofuscin-Like Substance}

According to the method of Yang, Su, Prasad, Yang, Cheng, Chen, Yang \& Jiang [15], frozen pericarp tissues (1 g) were extracted with $5 \mathrm{~mL}$ of ch1oroform:methanol:0.2 M phosphate buffer ( $\mathrm{pH} 5.3)(2: 2: 1, \mathrm{v} / \mathrm{v} / \mathrm{v})$ containing $2 \%(\mathrm{w} / \mathrm{v})$ butylated hydroxytolune (BHT). The resulting homogenate was treated for $10 \mathrm{~min}$ using ultrasonic cleaner (SB5200DTD, Xinzhi Biotech Co., Ningbo, China, $40 \mathrm{kHz}$ ) at $45{ }^{\circ} \mathrm{C}$, then mixed with $2 \mathrm{~mL}$ of $5 \mu \mathrm{M} \mathrm{CaCl}_{2}$, and finally centrifuged for $10 \mathrm{~min}$ at $1640 \mathrm{~g}$ to hasten phase separation. An aliquot of the chloroform phase was passed through a Sep-Pak silica cartridge (Waters Associates, Milford, MA) washed previously with $3 \mathrm{~mL}$ chloroform containing $0.7 \%$ (v/v) ethanol. Lipofuscin-like substance was eluted with methanol from the column into a tube containing 0.17 $\mathrm{mg} / \mathrm{mL}$ BHT. The elute was collected at $3 \mathrm{~mL} /$ tube. The fluorescence intensity of the elute was determined immediately using a Varian spectrofluorometer (Model SF 330, Saint-Jean-Sur-Richelieu, Quebec, Canada) at $360 \mathrm{~nm}$ and $425 \mathrm{~nm}$ used as excitation and emission wavelengths, respectively. The relative content of lipofuscin-like substance was expressed as the fluorescent value on fresh weight basis.

\subsection{Date Handling}

Data were expressed as means \pm standard deviations of three replications and then analysed by SPSS (Version 10.0, Spss inc, Chicago, USA). One-way analysis of variance (ANOVA) and Tukey multiple comparisons were carried out to test any significant differences between the means. The significant differences between the means within the confidence interval of $95 \%$ were analyzed by $t$-test.

\section{RESULTS AND DISCUSSION}

The emission spectra of lipofuscin-like substance obtained from pericarp tissue of litchi fruit during storage were presented in Fig. (1). A sharp increase in the fluorescence intensity at $425 \mathrm{~nm}$ of emission maxima and $360 \mathrm{~nm}$ of excitation maxima) was observed, which indicated that the content of lipofuscin-like substance increased as there was a little change (about $1 \%$ ) in the moisture of the pericarp was obtained in this storage period (data not shown). Furthermore, the accumulation of lipofuscin-like substance present in pericarp tissue of litchi fruit during storage was associated markedly with increasing browning index (Table 1). It was reported that fruit ripening or senescence was also related to the accumulation of lipofuscin-like substance in pear [4], banana $[4,15]$ and litchi [5].

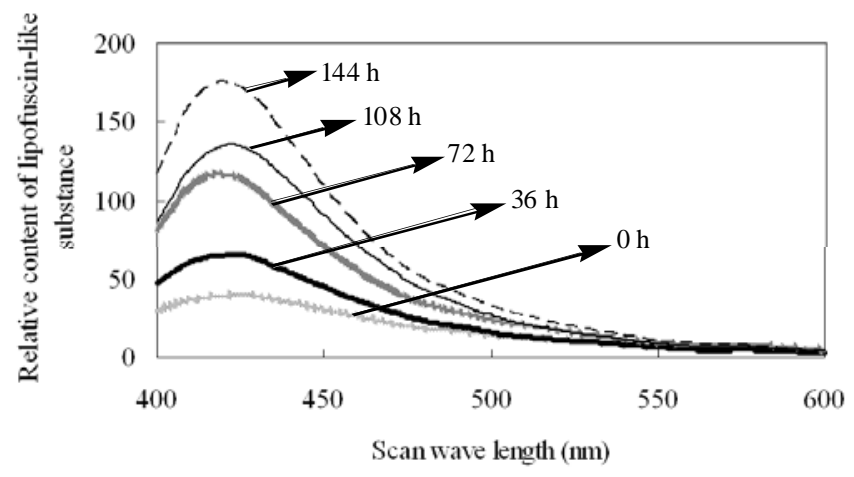

Fig. (1). Fluorescent emission spectrum of lipofuscin-like substance excited at $360 \mathrm{~nm}$ present in pericarp tissue of litchi fruit at various storage time.

Hendry, Houghton \& Brown [16] proposed the presence of lipofuscin-like substance in living tissue and speculated that lipofuscin-like substance in senescent plant tissue may involve in the breakdown products of chlorophyll originating from methane bridge carbon attached to two halves of pyrroles of macrocyclic ring. Düggelin, Bortlik, Gut, Matile \& Thomas [7] observed the different accumulation of lipofuscin-like substance in leaves of Festuca pratensis cv. Rossa, a yellowing genotype, and cv. Bf 993, a non-yellowing genotype. Adachi, Nakabayashi, Azuma, Kurata, Takahashi \& Shimokawa [17] proved the formation of lipofuscin-like substance in vitro by the catabolism of chlorophyll a in radish cotyledons.

The contents of (-)-epicatechin and anthocyanins of litchi fruit increased during the first $72 \mathrm{~h}$ and then decreased (Figs. 2 and 3). Similar results were reported by Zhang, Grigor \& Quantick [18], which could be attributed to the continuous biosyntheses of anthocyanin and (-)-epicatechin of litchi fruit at the early storage stage. In addition, Zhang, Pang, Yang, Ji \& Jiang [19] reported that a major anthocyanin of litchi fruit cv. 'Huaizhi' represented $94.3 \%$ of total anthocyanins, which accounted for one major peak of litchi anthocyanins in this study.

The most widely accepted proposal is that lipofuscin-like substance could be one of the final products of lipid peroxidation [2]. The reaction of aldehydes from the peroxidized 
Table 1. Changes in Contents of Anthocyanin, (-)-Epicachin and Lipofuscin-Like Substance, and Browning Index of Litchi Fruit at Various Storage Time

\begin{tabular}{|c|c|c|c|c|}
\hline $\begin{array}{c}\text { Storage of } \\
\text { Time (h) }\end{array}$ & $\begin{array}{c}\text { Anthocyanin Content (mg/g } \\
\text { FW) }\end{array}$ & $\begin{array}{c}\text { Relative Fluorescent Intensity of } \\
\text { Lipofuscin-Like Substance }\end{array}$ & Browning Index (\%) \\
\hline \hline 0 & $0.13 \mathrm{c}$ & $0.37 \pm 0.01 \mathrm{c}$ & $39.32 \pm 2.88 \mathrm{~d}$ & 0 \\
\hline 36 & $0.14 \pm 0.01 \mathrm{~b}$ & $0.38 \pm 0.03 \mathrm{c}$ & $44.44 \pm 3.51 \mathrm{~d}$ & 0.3 \\
\hline 72 & $0.20 \pm 0.01 \mathrm{a}$ & $0.55 \pm 0.04 \mathrm{a}$ & $113.31 \pm 6.72 \mathrm{c}$ & 12.5 \\
\hline 108 & $0.13 \pm 0.01 \mathrm{c}$ & $0.50 \pm 0.03 \mathrm{~b}$ & $134.11 \pm 10.64 \mathrm{~b}$ & 35.33 \\
\hline 144 & $0.10 \pm 0.01 \mathrm{~d}$ & $0.39 \mathrm{c}$ & $171.22 \pm 10.12 \mathrm{a}$ & 51.59 \\
\hline
\end{tabular}

Different letters within the same column indicated significant differences at $5 \%$ level.

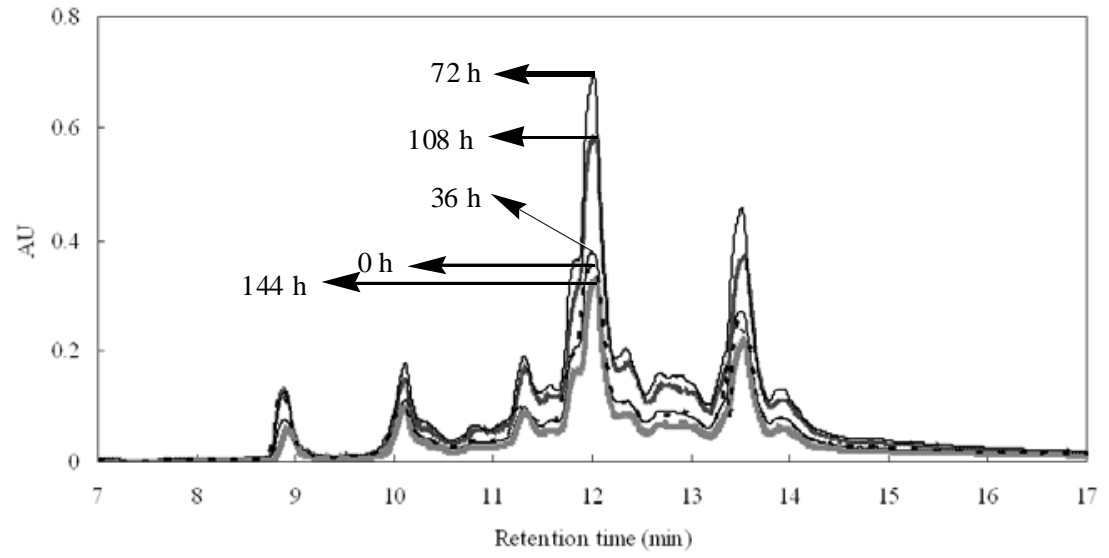

Fig. (2). HPLC analysis of (-)-epicatechin present in pericarp tissue of litchi fruit at various storage time.

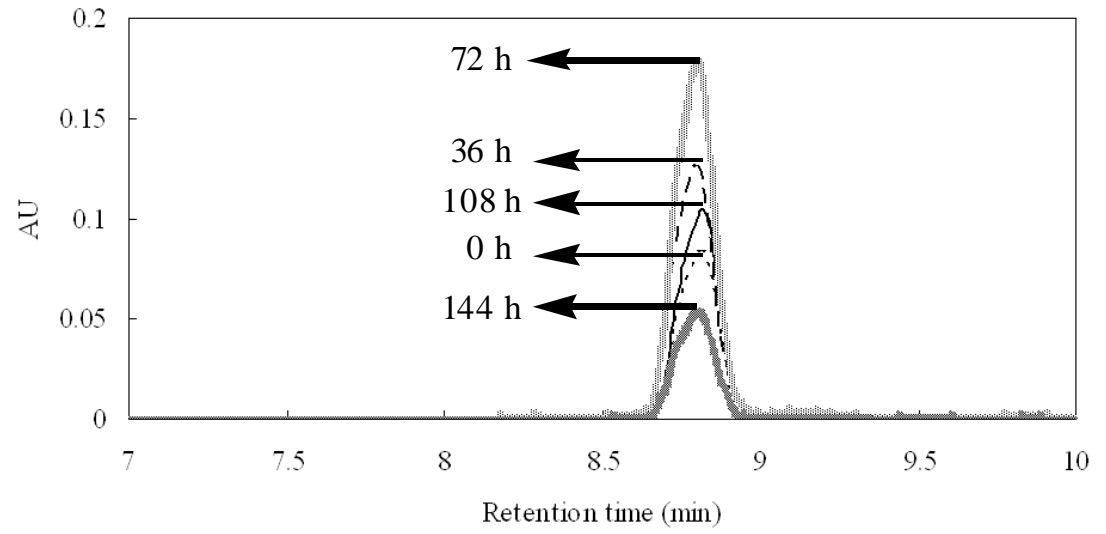

Fig. (3). HPLC analysis of anthocyanins present in pericarp tissue of litchi fruit at various storage time.

lipids and proteins could form lipofuscin-like substance exhibiting the fluorescent character of Schiff base structure [47]. In this study, browning index of litchi fruit after $72 \mathrm{~h}$ of storage increased rapidly (Table 1), which associated with the obvious accumulation of lipofuscin-like substance. As loss of compartmentalization of (-)-epicatechin and anthocyanins with polyphenol oxidase (PPO) or peroxidase (POD) initiates the enzyme-catalyzed oxidation in the presence of oxygen, the oxidative products can further react with proteins or lipids and then form the brown-colored by-products [20]. Moreover, the formation of browning color of tea ex- hibited a similar reaction of quinines with proteins and lipids $[21,22]$. Thus, it is suggested that lipofuscin-like substance could be the final brown polymeric pigment from browning reaction of litchi fruit during storage.

\section{CONFLICT OF INTEREST}

None declared.

\section{ACKNOWLEDGEMENTS}

We gratefully acknowledge the support of the National Natural Science Foundation of China (Grant No. 30425040) 
NSFC-Guangdong Joint Fund of Natural Sciences (Grant No. U0631004) and Guangdong Provincial Natural Science Foundation (Grant No. 06200670).

\section{REFERENCES}

[1] Wilhelmova N, Domingues PMDN, Srbova M, Fuksova H, Wilhelm J. Changes in nonpolar aldehydes in bean cotyledons during ageing. Biol Plant 2006; 50(4): 559-64.

[2] Chio S, Tappel AL. Synthesis and characterization of the fluorescent products. Biochemistry 1969; 8: 2821-7.

[3] Terman A, Gustafsson B, Brunk UT. Autophagy, organelles and ageing. J Pathol 2007; 211: 134-43.

[4] Maguire YP, Haard NF. Fluorescent product accumulation in ripening fruits. Nature 1975; 258: 599-600.

[5] Lin ZF, Wang W, Lin GZ, Chen JD. The changes of lipofuscin-like substance and organic free radicals. Prog Biochem Biophys 1988; 15: 377-9.

[6] Kumar GNM, Knowles NR. Changes in lipid peroxidation and lipolytic and free-radical scavenging enzyme activities during aging and sprouting of potato (solannum tuberosum) seed-tubers. Plant Physiol 1993; 102: 115-24.

[7] Düggelin T, Bortlik K, Gut H, Matile P, Thomas H. Leaf senescence in Festrca pratensis: accumulation of lipofuscin-like compounds. Physiol Plantrarum 1988; 74: 131-6.

[8] Jiang YM, Zauberman G, Fuchs Y. Partial purification and some properties of polyphenol oxidase extracted from litchi pericarp. Postharvest Biol Technol 1997; 10: 221-6.

[9] Jiang YM, Duan XW, Joyce DC, Zhang ZQ, Li JR. Advances in understanding enzymatic browning of harvested litchi fruit. Food Chem 2004; 88: 443-6.

[10] Zhang ZQ, Pang XQ, Duan XW, Ji ZL, Jiang YM. Role of peroxidase in anthocyanin degradation in litchi fruit pericarp. Food Chem 2005; 90: 47-52.
[11] Sun J, Jiang YM, Wei XY, et al. Identification of (-)-epicatechin as the direct substrate for polyphenol oxidase isolated from litchi pericarp. Food Res Int 2006; 39: 864-70.

[12] Lin ZF, Li SS, Zhang DL, Lin GZ, Li YB, Liu SX, Chen JD. The changes of pigments, phenolics contents and activities polyphenol oxidase and phenylalanine ammonia-lyase in pericarp of postharvest litchi fruit. Acta Bot Sin 1988; 30: 40-5.

[13] Zheng XL, Tian SP. Effect of oxalic acid on control of postharvest browning of litchi fruit. Food Chem 2005; 96: 519-23.

[14] Wrolstad RE, Culbertson JD, Cornwell C, Mattick LR. Detection of adulteration blackberry juice concentrates and wines. J Assoc Off Anal Chem 1982; 65: 1417-23.

[15] Yang SY, Su XG, Prasad KN, et al. Oxidation and peroxidation of postharvest banana fruit during softening. Pak J Bot 2008; 40: 2023-9.

[16] Hendry GAF, Houghton JD, Brown SB. The degradation of chlorophyll - a biological enigma. New Phytol 1987; 107: 255-302.

[17] Adachi M, Nakabayashi K, Azuma R, Kurata H, Takahashi Y, Shimokawa K. The ethylene-induced chlorophyll catabolism of radish (Raphanus sativus L.) cotyledons: production of colorless fluorescent chlorophyll catabolite (FCC) in vitro. J Japan Soc Hortic Sci 1999; 68: 1139-45.

[18] Zhang DL, Grigor JM, Quantick PC. Changes in phenolic compounds in litchi (Litchi chinensis Sonn.) fruit during postharvest storage. Postharvest Biol Technol 2000; 19: 165-72.

[19] Zhang ZQ, Pang XQ, Yang C, Ji ZL, Jiang YM. Purification and structural analysis of anthocyanins from litchi pericarp. Food Chem 2004; 84: 601-4.

[20] Jiang YM, Wang Y, Song L, et al. Postharvest characteristics and handing of litchi fruit. Aust J Exp Agric 2006; 46: 1541-56.

[21] Graham HN. Green tea composition, consumption, and polyphenol chemistry. Prevent Med 1992; 21: 334-50.

[22] Tanaka T, Kouno I. Oxidation of tea catechins: chemical structures and reaction mechanism. Food Sci Technol Res 2003; 9: 128-33.

Received: September 25, 2011

Revised: October 30, 2011

Accepted: November 10, 2011

(c) Yang et al.; Licensee Bentham Open.

This is an open access article licensed under the terms of the Creative Commons Attribution Non-Commercial License (http://creativecommons.org/licenses/by-nc/3.0/) which permits unrestricted, non-commercial use, distribution and reproduction in any medium, provided the work is properly cited. 